\title{
WOOD AND LEAF ANATOMY OF COPAIFERA LANGSDORFFII DWARF TREES
}

\author{
Eduardo L. Longui ${ }^{1 *}$, Natalia O. Costa ${ }^{1}$, Roque Cielo-Filho ${ }^{1}$, \\ Carmen R. Marcati ${ }^{2}$, Diego Romeiro ${ }^{3}$, Kishore S. Rajput ${ }^{4}$, Israel L. Lima ${ }^{1}$ and \\ Sandra M.B. Florsheim ${ }^{1}$ \\ ${ }^{1}$ Divisão de Dasonomia, Seção de Madeira e Produtos Florestais, Instituto Florestal, \\ São Paulo, SP, Brazil \\ ${ }^{2}$ Departamento de Ciência Florestal, Faculdade de Ciências Agronômicas, Universidade Estadual \\ Paulista, UNESP, Campus de Botucatu, SP, Brazil \\ 3Pós-graduação em Biodiversidade Vegetal e Meio Ambiente, Instituto de Botânica, \\ São Paulo, SP, Brazil \\ ${ }^{4}$ Department of Botany, Faculty of Science, The M.S. University of Baroda, \\ Vadodara-390002, India. \\ *Corresponding author; e-mail: elongui@if.sp.gov.br
}

\begin{abstract}
There are various parameters that affect tree height and may cause dwarfism. Our goal was to study the anatomical variations in the leaf and xylem structure in dwarf and normal trees of Copaifera langsdorffii and their correlation with physico-chemical properties of the soils. Trees from two spatially close but different vegetation types, transitional forest and rupestrian field, showed markedly different wood and leaf characteristics. Adult trees of $C$. langsdorffii show normal height (up to $25 \mathrm{~m}$ ) in transitional forests while in the rupestrian field they show dwarfism (small trees up to $2.5 \mathrm{~m}$ tall). Physical soil characteristics (such as rocky crust, low water availability due to shallow soil) presumably limit root growth and affect the rate of photosynthesis, which consequently affect the extension growth of the plant. Compared to normal trees, C. langsdorffii dwarf trees are characterized by narrow vessels and a higher proportion of vessels in multiples, features of the water transport system/hydraulic structure known to prevent embolism, wider rays with a greater potential to store starch, and higher stomatal density and potential conductance index.
\end{abstract}

Keywords: Ecological anatomy, dwarfism, plant strategies, rupestrian field, tropical woods.

\section{INTRODUCTION}

There are various parameters that affect tree height in general, such as availability of nutrients, limitations associated with xylem and phloem transport. Extreme limitation of height growth results in plant dwarfism. This may be caused by genetic defects or limited availability of various growth hormones, such as gibberellins and brassinosteroids (Sazuka et al. 2005), pathogenic bacteria (Hoshi et al. 2009), environmental 
conditions, as reported in mangroves under limited growing conditions (Lovelock et al. 2006; Naidoo 2006; Schmitz 2008), edaphic factors (Griffiths 2006), or by constant wind exposure (Lüttge 2008). From these studies, it is evident that environmental factors can be a major contributor to dwarfism in plants.

In the present investigation, during the field studies, we noticed that two vegetation types including transitional forest between forest and cerrado (Brazilian savanna), as well as rupestrian field growing spatially very close to each other, have markedly distinct soil and vegetation characteristics. The transitional forest soils are deep, dystrophic and well-drained while rupestrian field soils are shallow or confined to cracks between rocks. Both have low $\mathrm{pH}$ and low availability of calcium and magnesium, and high aluminum content (Oliveira-Filho \& Ratter 2002). Adult trees of Copaifera langsdorffii are of normal height in transitional forests, whereas in the rupestrian field, they show dwarfism. Both of these habitats are part of the Cerrado biome (Oliveira-Filho \& Ratter 2002; Ribeiro \& Walter 2008). Preliminary investigations showed conspicuous differences in the physico-chemical properties of the soils between transitional forests and rupestrian field, including pronounced differences in water holding capacity of the soil (Oliveira-Filho \& Ratter 2002; Reatto et al. 2008). On the basis of these observations, it was hypothesized that dwarfism in C. langsdorffii is a result of differences in water availability and soil characteristics. The question arose whether any anatomical differences exist in the leaf and wood anatomy of normal trees and dwarfs.

Durigan et al. (1997) and Carvalho (2003) also reported that in the cerrado and caatinga forest, $C$.langsdorffi trees are small to medium-sized, while in the rupestrian fields they are shrubs, small trees, or even dwarf trees showing stunted growth (personal observation).

Copaifera langsdorffii Desf. (Leguminosae), locally known as copaiba, is a representative species in the Brazilian flora, occurring naturally throughout the country, in addition to northeastern Argentina, southern Bolivia and northern Paraguay (Carvalho 2003; Paula \& Alves 2007). The species is semi-deciduous, occurring in early secondary, late successional, or climax communities. It has high phenotypic plasticity and varies in size depending on the vegetation. In the rain forest, adult trees may reach up to $35 \mathrm{~m}$ in height and about $100 \mathrm{~cm}$ in diameter at breast height. Marcati et al. (2001) investigated the phenotypic plasticity of wood displayed by $C$. langsdorffii trees growing in seasonal semi-deciduous forest and cerrado (Brazilian savanna). These authors observed a higher vessel diameter and a higher amount of gelatinous fibers in the wood of savanna trees, as well as larger intervessel pit diameters in the wood of semi-deciduous forest trees.

The main aim of the present investigation was to study the anatomical variations in the leaf and xylem structure in dwarf and normal trees and their correlation with physico-chemical properties of the soils.

\section{MATERIALS AND METHODS}

\section{Study area}

The study was carried out in two protected areas: the Itapeva Ecological Station (IEcS) and the Itapeva Experimental Station (IExS). The IEcS is located in the municipality of Itapeva, and the IExS in between the municipalities of Itapeva and Itaberá, 


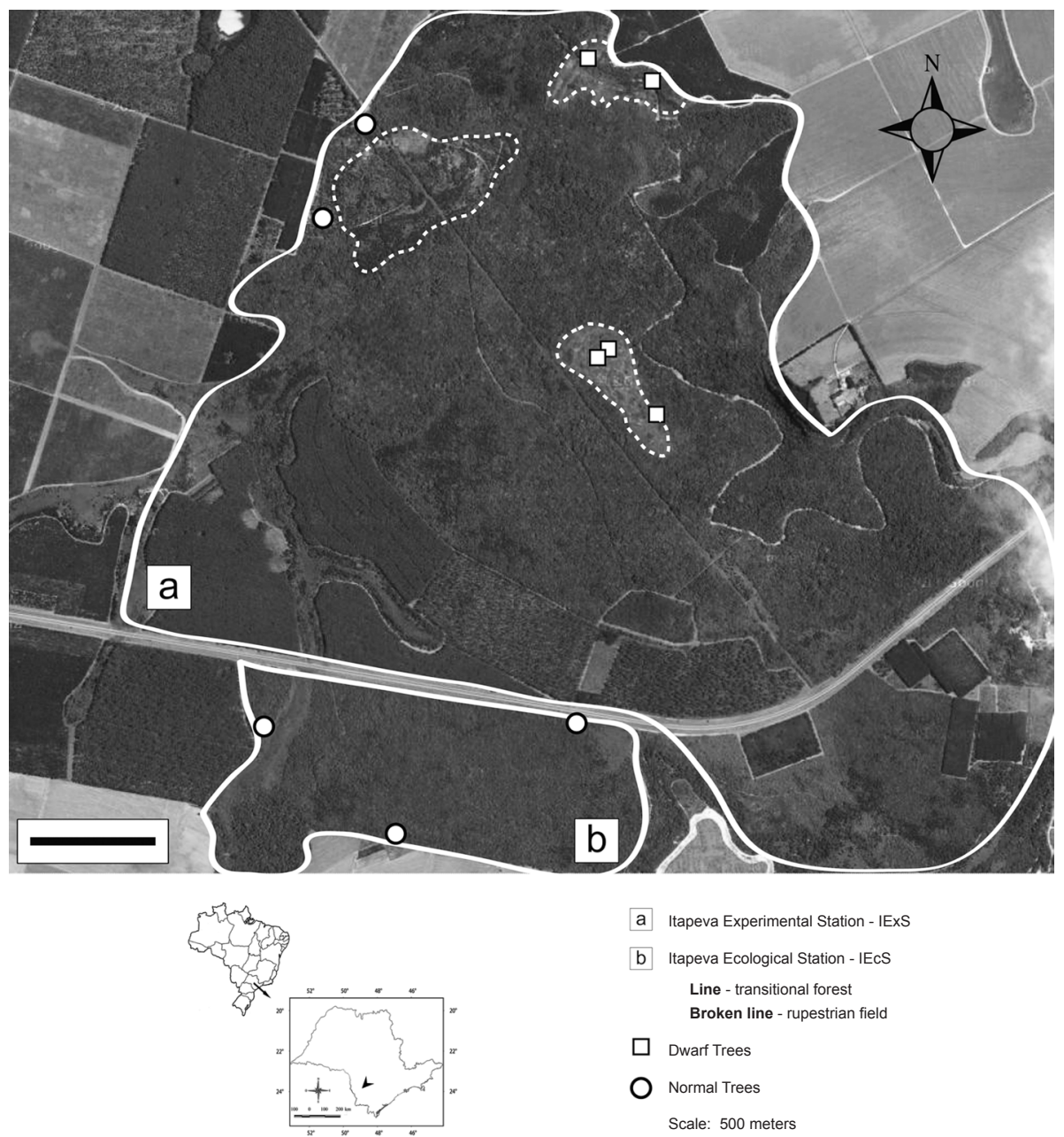

Figure 1. Studied areas and the location of Copaifera langsdorffii sampling. Small map below left: Brazil, São Paulo State magnified.

located in the southwest region of São Paulo State (Fig. 1). In both areas, we studied trees from two vegetation types that are spatially very close, but markedly distinct: transitional forest between seasonal semi-deciduous forest and cerrado (Brazilian savanna) and rupestrian field (Fig. 1). Overviews of the two areas are given in Figure 2.

\section{Soil sampling and analysis}

Soil samples were collected at depths between $0-20 \mathrm{~cm}$ in the vicinity (less than $3 \mathrm{~m}$ apart) of the sampled trees from the two habitats: transitional forest and rupestrian field. Air-dried soil samples were analyzed for phosphorus (P); aluminum (Al); $\mathrm{H}+\mathrm{Al}$; aluminum saturation $(\mathrm{m} \%)$; the basic cations, including potassium $(\mathrm{K})$, calcium $(\mathrm{Ca})$, and magnesium (Mg); sum of the bases $\mathrm{Ca}, \mathrm{Mg}$ and $\mathrm{K}(\mathrm{SB})$; $\mathrm{pH}$; base saturation (V\%); 

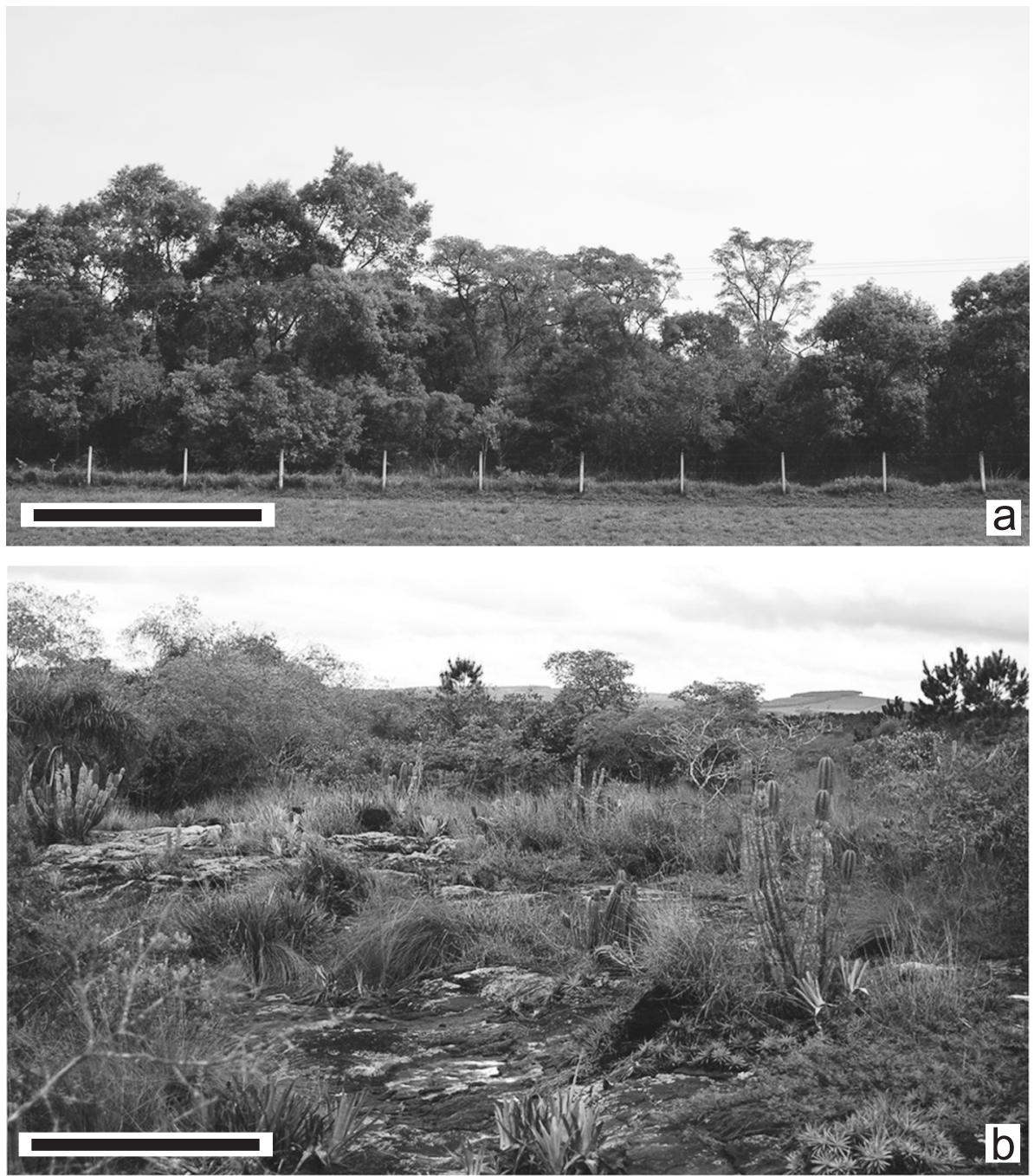

Figure 2. Overview of the sampling areas for soil, wood and leaves of Copaifera langsdorffii.a: Transitional forest, scale bar $=10 \mathrm{~m}$. - b: Rupestrian field, scale bar $=1 \mathrm{~m}$.

micronutrients boron $(\mathrm{B})$, copper $(\mathrm{Cu})$, iron $(\mathrm{Fe})$, manganese $(\mathrm{Mn})$ and zinc $(\mathrm{Zn})$; cation exchange capacity (CEC); total organic carbon (O.M.). Soil analysis was carried out as per the procedures described by Raij et al. (2001).

\section{Wood anatomy}

We sampled 10 trees of Copaifera langsdorffii, five from Itapeva Ecological Station, and five from Itapeva Experimental Station. As the areas are protected it was not allowed to collect trunk samples, and we therefore collected main branches. Based on the small size of rupestrian field plants, we standardized $\sim 4 \mathrm{~cm}$ for 
the branch diameter to avoid differences due to dimensions of samples in both areas. Mature leaves were collected from these branches.

Sapwood samples of $1.5 \mathrm{~cm}^{3}$ from each tree were softened in boiling water and glycerin $(4: 1)$ for $2 \mathrm{~h}$. From these samples, transverse and longitudinal sections of 15-20 $\mu \mathrm{m}$ thick were obtained with a sliding microtome. Sections were bleached with sodium hypochlorite $(60 \%)$, washed thoroughly in water, and stained with $1 \%$ safranin (Johansen 1940). Small portions of wood from each sample were macerated using Franklin's method (Berlyn \& Miksche 1976, modified), stained with aqueous safranin and mounted temporarily in a solution of water and glycerin (1:1). Measurements followed the recommendations of the IAWA Committee (1989).

Quantitative data were based on 25 for each feature and 10 for pits; the statistical requirements for minimum numbers of measurements were fulfilled: $\mathrm{N}=(\mathrm{t} \text { value })^{2} \times$ (sample variance) $/(\text { accuracy of } 10 \% \times \text { sample mean })^{2}$, following Freese (1967) and Eckblad (1991).

\section{Specific gravity}

The specific gravity was determined according to Glass and Zelinka (2010). Samples without bark were dried at standard temperature to reach about $12 \%$ moisture content to obtain volume of wood with a caliper (accuracy: 0.01-0.05 mm). Then, the oven-dried mass was determined with a semi-analytical balance.

\section{Leaf anatomy}

The collected leaves were fixed in FAA for 48 hours and then stored in $70 \%$ alcohol. For clearing, the leaves were boiled about four minutes, half the time in $95 \%$ alcohol and the remaining time in a solution of $5 \%$ sodium hydroxide and $95 \%$ alcohol (1:1). After this treatment, the leaves were placed in an aqueous solution of $20 \%$ sodium hypochlorite for bleaching (Strittmatter 1973, modified). Subsequently, the material was rinsed in water, and stained in an aqueous solution of astra blue (1\%) and safranin (1\%) $(9: 1)$, and mounted as semi-permanent slides (Kraus \& Arduin 1997). Three leaves from each tree were chosen to measure stomatal length and density ( $n=25$ for each leaf), and the potential conductance index [= (guard cell length $)^{2}$ stomatal density $10^{-4}$ ] was calculated by following Holland and Richardson (2009).

All anatomical measurements (wood and leaves) were obtained with a light microscope (Olympus CX 31) equipped with a camera (Olympus Evolt E330) and a computer with image analysis software (Image-Pro Plus 6.3).

\section{Statistical analysis}

Descriptive statistical analysis was performed to obtain the means and standard deviations used to test differences between groups; "t-test sample size" was used to confirm that the number of measurements was sufficient to achieve the desired power for the test (0.9). Subsequently from the normal distribution of data, the t test was used to determine which anatomical features varied significantly between samples from the two habitats. Linear regression was also performed to relate vessel diameter and vessel frequency with specific gravity. 


\section{RESULTS}

Physico-chemical parameters of the soil from transitional forest and rupestrian field showed considerable variation in the composition and nutrient content (see Table 1). Rupestrian field soil has a lower $\mathrm{pH}$ and higher organic, CEC and nutrient content, in addition to higher aluminum levels. The base saturation is smaller in rupestrian field while the aluminum saturation is greater.

Wood samples collected from transitional forest showed longer vessel elements with larger diameters as compared to trees growing in the rupestrian forest. However, vessel frequency did not differ between the branchwood samples from both habitats (Table 2). In transitional forest, vessels were mostly solitary while samples collected from the rupestrian field not only showed a higher density of vessels but also a higher degree of vessel grouping, with multiples of 3 or 4 or more (Fig. 3, 4). Intervessel pits and vessel-ray pits with larger diameters occurred in rupestrian field trees (Table 2). However, no variation was observed in length or wall thickness for the fibers between the wood samples of both habitats (Table 2). Though there was no significant difference in ray height between both habitats, the trees in transitional forest had a higher ray frequency as compared to rupestrian field trees. In contrast, ray width was found to be greater in plants growing in the rupestrian field (Table 2 and Fig. 5).

Specific gravity was higher in trees growing in the rupestrian field (Table 2). A negative relation was observed between specific gravity and vessel diameter in the rupestrian field (Fig. 6). In leaves, stomatal length did not vary between transitional forest and rupestrian field. However, stomatal frequency and potential conductance index were higher in the rupestrian field trees (Table 2 and Fig. 7).

\section{DISCUSSION}

\section{Soil nutrients}

In spite of the greater amount of macronutrients, sum of bases, and cation exchange capacity which might favor plant growth, we found smaller base saturation (V\%) in the soil of the rupestrian field because of its lower $\mathrm{pH}$ and higher aluminum saturation, which indicates a poorer nutritional status. Thus, the smaller V\% in rupestrian field soil might be considered as a factor playing a role in dwarfism of Copaifera langsdorffii trees. On the other hand, earlier studies report no differences in soil fertility when comparing trees with different statures in different habitats within the Cerrado biome (Haridasan 1992; Marimon \& Haridasan 2005).

The effects of mineral toxicity on the development of cultivated plants depend on soil $\mathrm{pH}$; for instance, manganese toxicity is observed at $\mathrm{pH}$ values lower than 5.6, while aluminum and iron become toxic for crops at $\mathrm{pH}$ values below 5 and 4, respectively (Haridasan 2008). Both habitats in the present study showed the presence of some degree of aluminum (Al) and manganese (Mn) toxicity. However, some native species from the Cerrado biome show no negative effects in their vegetative or reproductive growth even in the presence of high $\mathrm{Al}$ concentrations since these species have developed tolerance to high concentrations of Al, by its accumulation (Haridasan 1992; Haridasan \& Araújo 2005). Another form of Al resistance is by its exclusion, which seems to be 


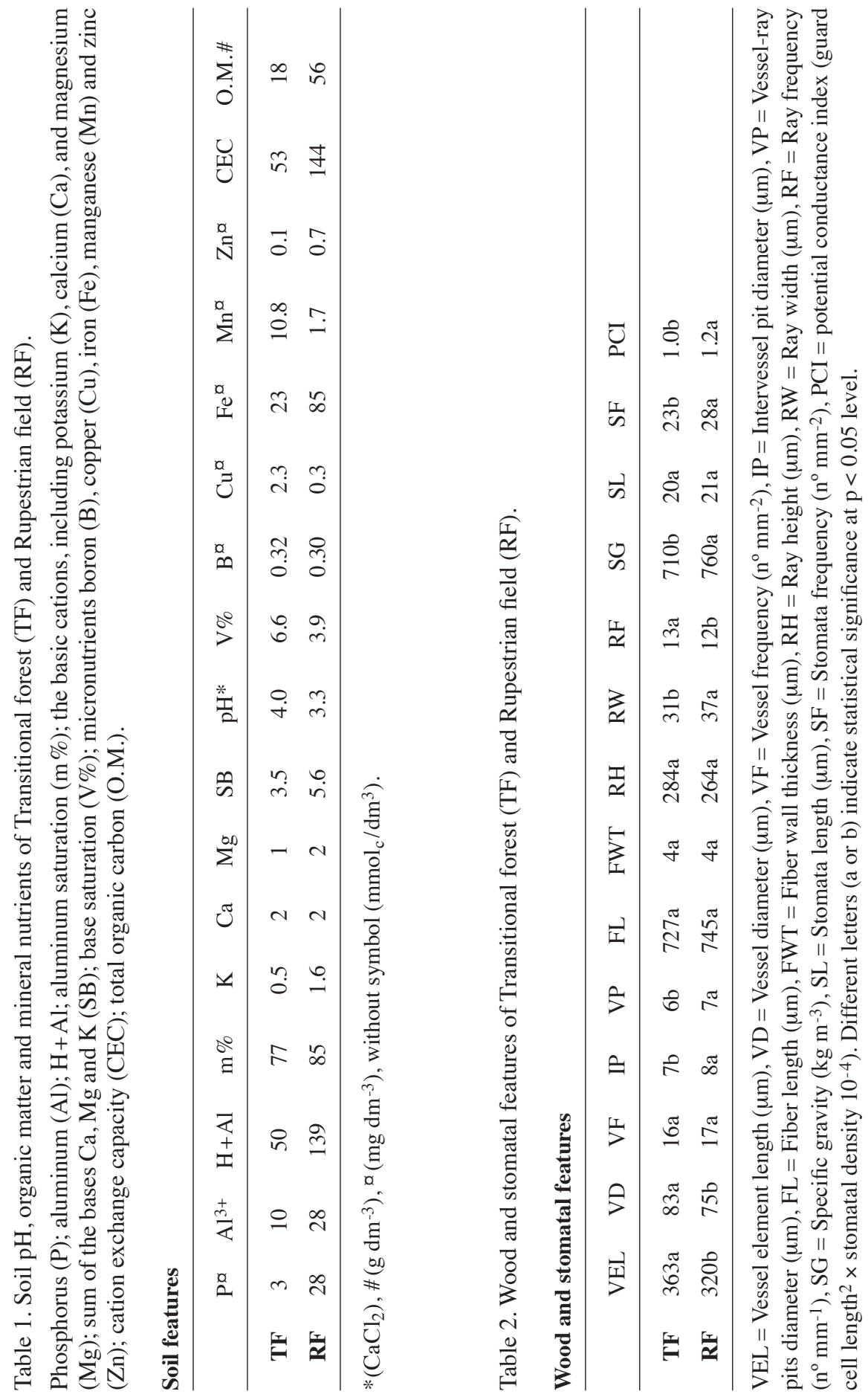




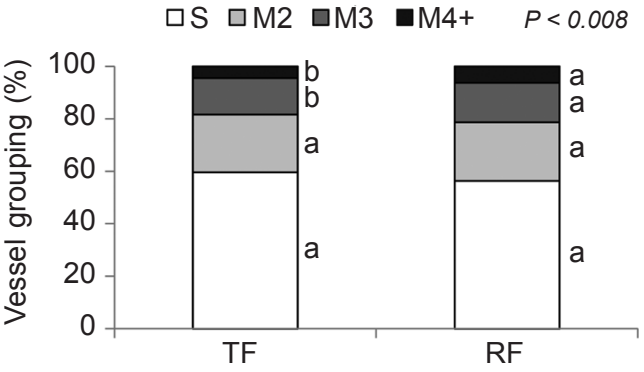

Figure 3. Proportion of vessel grouping in Copaifera langsdorffii wood. $-\mathrm{S}=$ solitary vessel, M2 $=$ multiples of $2, \mathrm{M} 3=$ multiples of $3, \mathrm{M} 4=$ multiples of 4 or more vessels; $\mathrm{TF}=$ transitional forest, $\mathrm{RF}=$ rupestrian field.

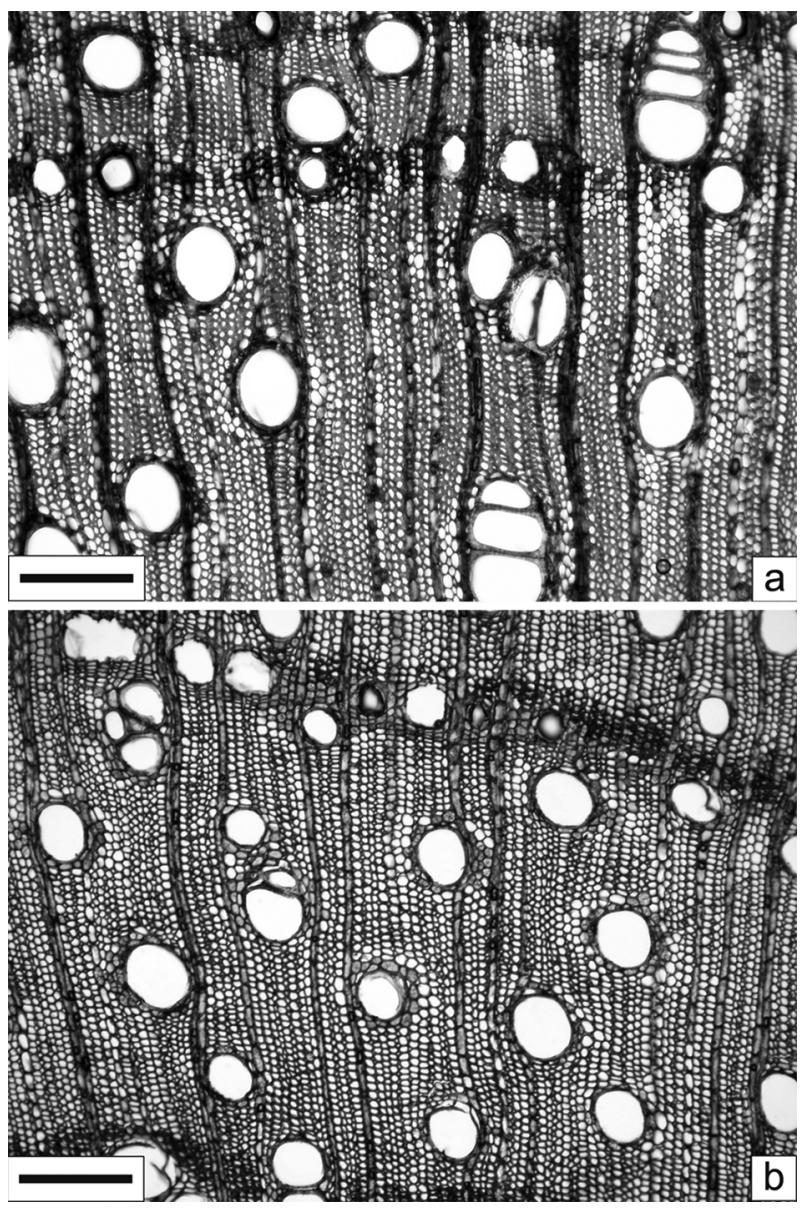

Figure 4. Transverse sections of Copaifera langsdorffii wood. - a: Transitional forest. - b: Rupestrian field. Note the larger diameter vessels in the wood of transitional forest trees. - Scale bars $=200 \mu \mathrm{m}$. 

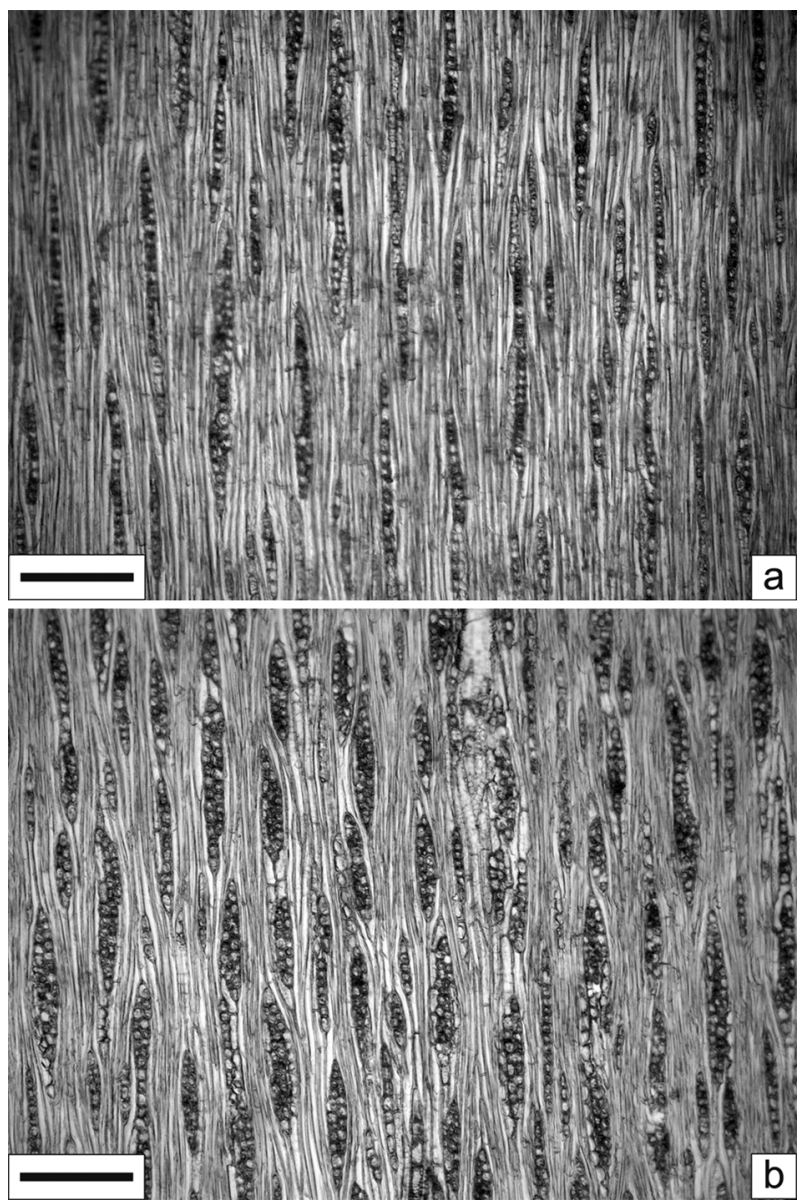

Figure 5. Tangential sections of Copaifera langsdorffii wood. - a: Transitional forest. - b: Rupestrian field. Note the wider rays in the wood of dwarf trees compared to the rays of trees with normal height in Fig. 5a. - Scale bars $=200 \mu \mathrm{m}$.

the strategy of $C$. langsdorffii trees, as indicated by the leaf concentration of $\mathrm{Al}$ and mineral nutrients in trees of this species growing in distrophic and mesotrophic soils in the Cerrado (Haridasan \& Araújo 1988). Al exclusion mechanisms rely mainly on the release of ligands, such as organic acid anions, which chelate Al limiting its uptake in the root symplast (Brunner \& Sperisen 2013). The metabolic costs of such mechanisms may reduce the relative growth rate of aluminum excluders, thus contributing to plant dwarfism. On the other hand, resistance mechanisms may not be efficient enough to cope up with high Al concentrations. For instance, the dwarfism of Pinus contorta subsp. bolanderi growing in acidic soils in Mendocino County, California was attributed to Al toxicity, which limits the root and whole plant growth (Westman 1975). For $P$. contorta subsp. bolanderi, a gene conferring aluminum resistance was almost com- 


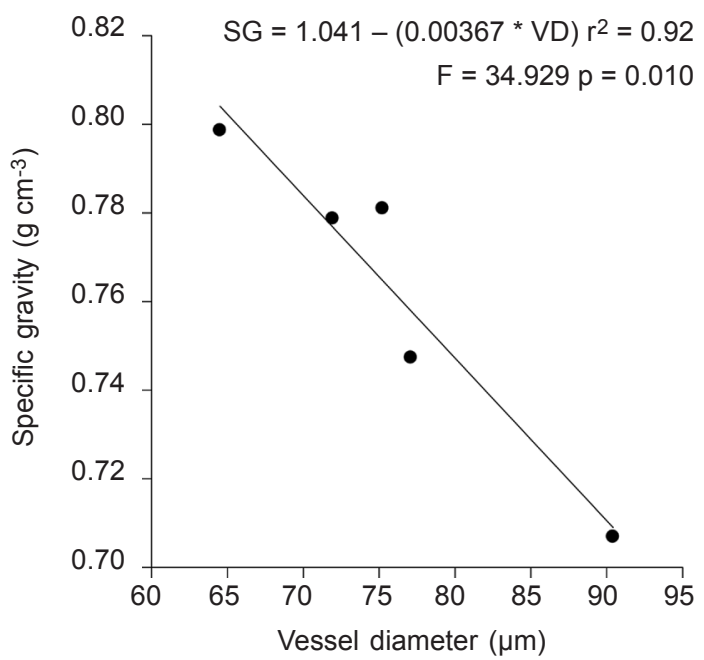

Figure 6. Relationship between specific gravity and vessel diameter in rupestrian field (five trees).

pletely fixed in the population, while in the normal statured subspecies $P$. contorta subsp. contorta, growing in soils with lower aluminum concentration nearby, that gene was extremely rare (Eckert et al. 2012). This showed that even Al resistant ecotypes may show a dwarf or pigmy habit. In other words, $\mathrm{Al}$ resistance may not be sufficient to prevent dwarfism. Haridasan and Araújo (2005) considered C. langsdorffii as a $\mathrm{Mn}$ accumulator species, but such dwarfism cannot be correlated with the higher con-centration of manganese in the rupestrian field, because of its relatively low concentration. Iron toxicity remains another possible factor contributing to $C$. langsdorffii dwarfism; this source of toxicity has also been discussed for native species growing in acidic soils (Haridasan \& Araújo 2005). Whether metabolic costs related with aluminum resistance or residual aluminum toxicity could be responsible for dwarfism of C. langsdorffi trees in rupestrian field, should be addressed in further studies.

According to Naidoo (2006) phosphorus-limitation levels are the cause for dwarfism in mangroves. In the present study we found a higher P concentration in soil where dwarf plants grow that might be causal in the differences in growth rate either by growth inhibition or other mechanism not studied here. It is possible that one mineral or a combination of minerals could contribute to dwarfism in $C$. langsdorffii.

\section{Soil structure}

Trees of the rupestrian field grow in shallow soil that occurs in depressions and cracks of the rocks, making it difficult to develop roots and consequently affecting the growth of stem and crown. Baas et al. (1984) associated dwarfism to slow growth in a study of wood in selected dicot and conifer trees. Some of their natural and man-made dwarfs (bonsais) were limited in their growth by restrictions to the root systems in rock cracks or plant pots. Thus, dwarfism in the rupestrian field trees might be associated with limitations of root growth, as it is difficult for the roots to penetrate into the rocky substratum. 

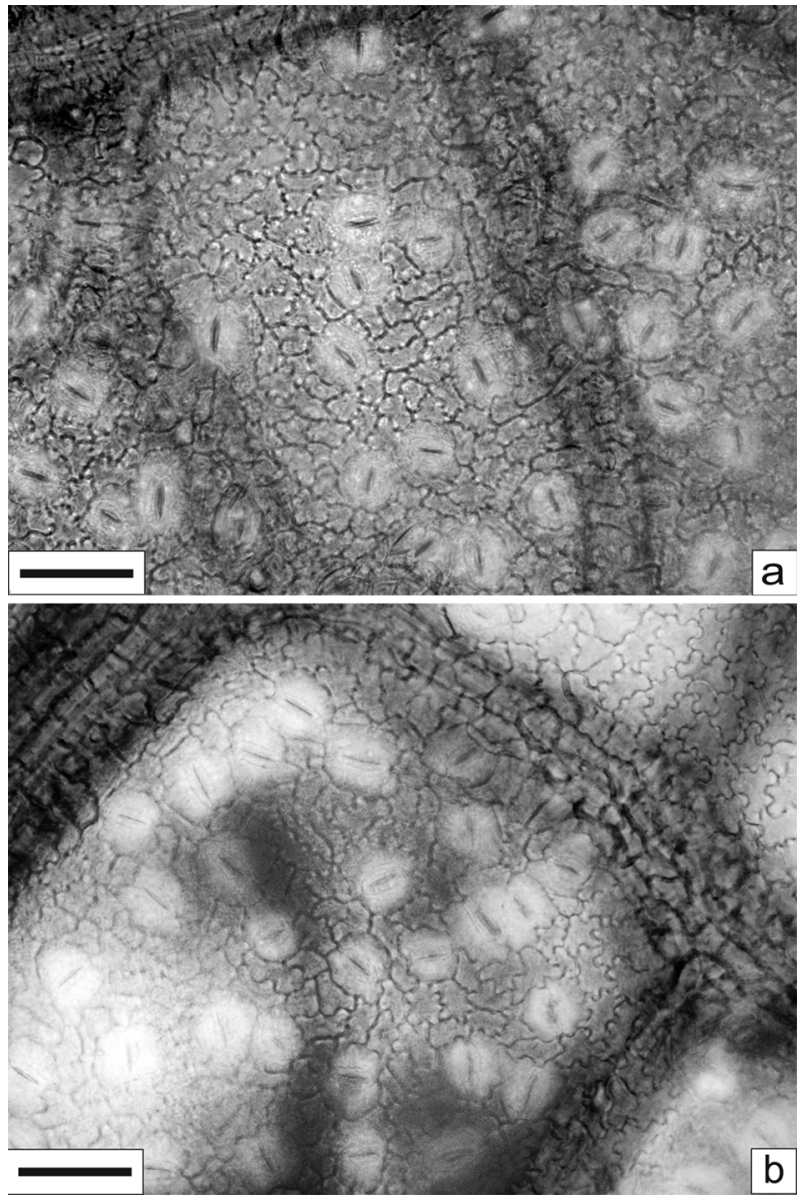

Figure 7. Abaxial surface of leaves. - a: Transitional forest. - b: Rupestrian field. Note the higher stomatal density in the leaves of dwarf plants when compared with the trees of normal height shown in Fig. 7a. - Scale bars $=50 \mu \mathrm{m}$.

\section{Soil water availability}

Remarkable differences are also observed in available water holding capacity of the soil in the rupestrian field (Entisols) and transitional forest (Oxisols). Water availability in the soil of the rupestrian field was much lower than the soil of the transitional forest (Reatto et al. 2008). It is well known that soil water plays a crucial role in plant growth and development (Kramer \& Kozlowski 1979). Reduced water availability in the rupestrian field may therefore pose serious restrictions for the extension growth of the plant in this habitat which can be inferred from plant size, as well as wood and leaf anatomical features. Thus, the reduced water availability in the soil of the rupestrian field is another plausible factor responsible for dwarfism. The drought stress in the rupestrian field also was correlated with higher wood specific gravity of dwarf trees. 


\section{Comparative wood and leaf anatomy between dwarf and normal trees}

In functional terms, shorter vessel elements with smaller vessel diameter might be an adaptation to protect vessels against cavitation (Hacke et al.2005), which might be occurring in the rupestrian field trees. Olson and Rosell (2013) stated that vessel diameter appears to vary between species depending on the size of the stem, likely as the result of selection favoring vessels with an optimal balance between hydraulic conductivity and vulnerability to cavitation given conductive path length. At the same time, average vessel diameter often varies with habitat. These views are compatible if selection, when it increases cavitation resistance via narrow vessels, also reduces stature.

The effects of dwarf growth on wood structure of 13 species of artificially induced or naturally occurring dwarf trees were studied by Baas et al. (1984), who found higher vessel frequency and lower vessel diameter in dwarf trees as compared to normal ones. Our results partially differ from the observations of Baas et al. (1984); in the present study no such variation was observed in vessel frequency in branches of trees of different sizes.

Vessel diameter variation between normal (tall) and dwarf (short) trees might be due to tree size as Anfodillo et al. $(2006,2013)$ have suggested that the degree of conduits tapering is strongly related to the tree height independently of any other variable (age, site, altitude, etc.).

Stronger vessel grouping (vessel multiples of 3 or 4 or more) in trees growing in the rupestrian field may indicate a reduced risk of air embolism. Greater vessel grouping in stressful environments is an adaptive condition that has already been reported in several studies (Carlquist 1984, 2009), e.g., Robert et al. (2009) who compared vessel grouping of Avicennia marina and Rhizophora mucronata, indicating that higher vessel grouping occurred under high salinity. According to Ellmore and Ewers (1985) wide vessels are vulnerable to air embolism while narrow vessel elements are as effective as tracheids.

Trees growing in the rupestrian field have larger intervessel and ray-vessel pits when compared to the transitional forest trees. Pit structure has been showed to be correlated with hydraulic conductivity (Lens et al.2011; Jansen et al. 2011). Small pits with reduced pore size have been considered as a strategy to decrease the incidence of embolism (Baas et al. 1983; Tyree et al. 1994; Sperry \& Hacke 2004). In the present study, in addition to pit attributes, smaller diameter vessels may contribute to avoid embolisms. Additionally, we emphasize that vestures in pits (a typical characteristic of the Leguminosae family), as previously reported by Jansen et al. (2003), might help in the avoiding of embolisms.

Higher wood density in rupestrian field trees was related to the smaller vessel diameter. We believe that these features contribute to an increase in strength to prevent breakage by wind, a condition often present in the open vegetation of the rupestrian field.

Wider rays in rupestrian field trees may be related to greater storage capacity. Starch, as a source of sugars, would be important in view of limited photosynthesis in these trees by the low water availability in the soil. Similar results were noted in other Brazilian species by Luchi (2004) who also found wider rays in drier environments in Croton urucurana and Lima et al. (2009) in Enterolobium contortisiliquum. Expanded rays 
in cacti stored water in wood tissues (Stone-Palmquist \& Mauseth 2002). Perhaps bulky rays in the rupestrian field can also contribute to water storage.

We did find a higher stomatal density and potential conductance index in the rupestrian field trees, which could be related to water stress and growth conditions of roots in rocky soil. The relationship between stomatal density and water stress is cited in several studies with different types of plants (Xu \& Zhou 2008; Fraser et al. 2009; Gan et al. 2010; Peterson et al. 2012). We highlight Camargo and Marenco (2011) who studied stomatal density in 35 tree species in the Central Amazonian rain forest and found a positive relationship between stomatal density and tree height, contrary to our results; however, the study of Camargo and Marenco was not conducted with dwarf trees.

The higher potential conductance index in rupestrian field trees might provide higher efficiency in gaseous exchange during the period in which the stomata are open and can remain open for a short period. This could explain why soil with low water storage capacity, such as that found in the rupestrian field is easily associated with plants having higher stomatal density. In a classic paper, Salisbury (1927) studied more than 300 species of the Great Britain flora and noted that stomatal density is greater in drier conditions (cf. Lleras 1974).

\section{CONCLUSIONS}

Soil characteristics of rupestrian field contribute to the occurrence of dwarfism in Copaifera langsdorffi: the metabolic costs to exclude aluminum as well as phosphorus excess could contribute to the dwarfism; dwarfism cannot be correlated with the higher concentration of manganese in the rupestrian field because of its relatively low concentration; iron toxicity remains another possible factor contributing to dwarfism. Trees from the rupestrian field show typical features of plants growing in dry habitats and stressful environments with smaller vessel diameters and higher vessel grouping which may be related to increased hydraulic safety. Furthermore, wider rays might be associated with greater potential to store starch while higher stomatal density and a potential conductance index might provide greater efficiency in gaseous exchange when stomata are open. Furthermore, poor water holding capacity along with residual aluminum toxicity may be responsible for the dwarfism in the rupestrian field but further studies are required to confirm this.

\section{ACKNOWLEDGEMENTS}

The authors thank Sonia Regina Godói Campião (Instituto Florestal) for laboratory assistance and Conceição Rodrigues Lima (Forestry Institute) for field assistance. We also thank Conselho Nacional de Desenvolvimento Científico e Tecnológico - CNPq (National Council for Scientific and Technological Development) for a grant to Natalia de Oliveira Costa.

\section{REFERENCES}

Anfodillo T, Carraro V, Carrer M, Fior C \& Rossi S. 2006. Convergent tapering of xylem conduits in different woody species. New Phytol. 169: 279-290. 
Anfodillo T, Petit G \& Crivellaro A. 2013. Axial conduit widening in woody species: a still neglected anatomical pattern. IAWA J. 34: 352-364.

Baas P, Chenglee L, Xinying Z, Kerning C \& Yuefen D. 1984. Some effects of dwarf growth on wood structure. IAWA Bull. n.s. 5: 45-63.

Baas P, Werker E \& Fahn A. 1983. Some ecological trends in vessel characters. IAWA Bull. n.s. 4: 141-159.

Berlyn GP \& Miksche JP. 1976. Botanical microtechnique and cytochemistry. Iowa State University Press, Ames, IA.

Brunner I \& Sperisen C. 2013. Aluminum exclusion and aluminum tolerance in woody plants. Frontiers in Plant Science 4: 172.

Camargo MAB \& Marenco RA. 2011. Density, size and distribution of stomata in 35 rainforest tree species in Central Amazonia. Acta Amaz. 41: 205-212.

Carlquist S. 1984. Vessel grouping in dicotyledon wood: significance and relationship to imperforate tracheary elements. Aliso 10: 505-525.

Carlquist S. 2009. Non-random vessel distribution in woods: patterns, modes, diversity, correlations. Aliso 27: 39-58.

Carvalho PER. 2003. Espécies arbóreas brasileiras. Embrapa Informações Tecnológica, Colombo.

Durigan G, Figliolia MB, Kawabata M, Garrido MAO \& Baitello JB. 1997. Sementes e mudas de árvores tropicais. Páginas e Letras, São Paulo.

Eckblad JW. 1991. How many samples should be taken. Bio Science 41: 346-348.

Eckert AJ, Shahi H, Datwyler SL \& Neale DB. 2012. Spatially variable natural selection and the divergence between parapatric subspecies of lodgepole pine (Pinus contorta, Pinaceae). Amer. J. Bot. 99: 1323-1334.

Ellmore GS \& Ewers FW.1985. Hydraulic conductivity in trunk xylem of elm, Ulmus americana. IAWA J. 6: 303-307.

Fraser LH, Greenall A, Carlyle C, Turkington R \& Friedman CR. 2009. Adaptive phenotypic plasticity of Pseudoroegneria spicata: Response of stomatal density, leaf area and biomass to changes in water supply and increased temperature. Ann. Bot. 103: 769-775.

Freese F. 1967. Elementary statistical methods for foresters. USDA Forest Service, Agriculture Handbook 317, Washington.

Gan Y, Zhou L. Shen ZJ, Shen ZX, Zhang YQ \& Wang GX. 2010. Stomatal clustering, a new marker for environmental perception and adaptation in terrestrial plants. Botanical Studies 51: 325-336.

Glass S \& Zelinka SL. 2010. Moisture relations and physical properties of wood. In: Ross R (ed.), Wood handbook, Centennial Edition. FPL-GTR-190. US Department of Agriculture, Forest Service, Forest Products Laboratory.

Griffiths ME. 2006. Salt spray and edaphic factors maintain dwarf stature and community composition in coastal sandplain heathlands. Plant Ecology 186: 69-86.

Hacke UG, Sperry JS \& Pittermann J. 2005. Efficiency versus safety tradeoffs for water conduction in angiosperm vessels versus gymnosperm tracheids. In: Holbrook NM \& Zwienniecki MA (eds.), Vascular transport in plants: 333-354. Elsevier Inc., Amsterdam.

Haridasan M. 1992. Observations on soils, foliar nutrient concentration and floristic composition of cerrado sensu stricto and cerradão communities in central Brazil. In: Furley PA, Proctor J \& Ratter JA (eds.), Nature and dynamics of forest-savanna boundaries: 171-184. Chapman $\&$ Hall Publishing, London.

Haridasan M. 2008. Nutritional adaptations of native plants of the cerrado biome in acid soils. Braz. J. Plant Physiol. 20: 183-195.

Haridasan M \& Araújo GM. 1988. Aluminium accumulating species in two forest communities in the cerrado region of central Brazil. Forest Ecology and Management 24: 15-26. 
Haridasan M \& Araújo GM. 2005. Perfil nutricional de espécies lenhosas de duas florestas semidecíduas em Uberlândia, MG. Rev. Brasileira Bot. 28: 295-303.

Holland N \& Richardson AD. 2009. Stomatal length correlates with elevation of growth in four temperate species. J. Sustainable For. 28: 63-73.

Hoshi A, Oshima K, Kakizawa S, Ishii Y, Ozeki J, Hashimoto M, Komatsu K, Kagiwada S, Yamaji Y \& Namba S. 2009. A unique virulence factor for proliferation and dwarfism in plants identified from a phytopathogenic bacterium. PNAS 106: 6416-6421.

IAWA Committee. 1989. IAWA list of microscopic features for hardwood identification. IAWA Bull. n.s. 10: 219-332.

Jansen S, Baas P, Gasson P \& Smets E. 2003. Vestured pits: Do they promote safer water transport? Int. J. Plant Sci. 164: 405-413.

Jansen S, Gortan E, Lens F, Lo Gullo MA, Salleo S, Scholz A, Stein A, Trifilò P \& Nardini A. 2011. Do quantitative vessel and pit characters account for ion-mediated changes in the hydraulic conductance of angiosperm xylem? New Phytol. 189: 218-228.

Johansen DA. 1940. Plant microtechnique. McGraw-Hill Book Co., Inc., New York.

Kramer PJ \& Kozlowski TT. 1979. Physiology of woody plants. Academic Press, New York.

Kraus JE \& Arduin M. 1997. Manual básico de métodos em morfologia vegetal. Rio de Janeiro, EDUR. 25 pp.

Lens F, Sperry JS, Christman MA, Choat B, Rabaey D \& Jansen S. 2011. Testing hypotheses that link wood anatomy to cavitation resistance and hydraulic conductivity in the genus Acer. New Phytol. 190: 709-723.

Lima RS, Oliveira PL \& Rodrigues LR. 2009. Anatomia do lenho de Enterolobium contortisiliquum (Vell.) Morong (Leguminosae-Mimosoideae) ocorrente em dois ambientes. Rev. Brasil Bot. 32: 361-374.

Lleras E. 1974. Differences in stomatal number per unit are within the same species under different micro-environmental conditions: A working hypothesis. Acta Amazonica 7: 473-476.

Lovelock CE, Ball MC, Choat B, Engelbrecht BMJ, Holbrook NM \& Feller IC. 2006. Linking physiological processes with mangrove forest structure: phosphorus deficiency limits canopy development, hydraulic conductivity and photosynthetic carbon gain in dwarf Rhizophora mangle. Plant Cell Environm. 29: 793-802.

Luchi AE. 2004. Anatomia do lenho de Croton urucurana Baill. (Euphorbiaceae) de solos com diferentes níveis de umidade. Rev. Brasil Bot. 27: 271-280.

Lüttge U. 2008. Physiological ecology of tropical plants. Ed. 2. Springer Verlag, Berlin.

Marcati CR, Angyalossy-Alfonso V \& Benetati L. 2001. Anatomia comparada do lenho de Copaifera langsdorffii Desf. (Leguminosae-Caesalpinioideae) de floresta e cerradão. Rev. Brasil Bot. 24: 311-320.

Marimon Júnior BH \& Haridasan M. 2005. Comparação da vegetação arbórea e características edáficas de um cerradão e um cerrado sensu stricto em áreas adjacentes sobre solo distrófico no leste do Mato Grosso, Brasil. Acta Bot. Bras. 19: 913-926.

Naidoo G. 2006. Factors contributing to dwarfing in the mangrove Avicennia marina. Ann. Bot. 97: 1095-1101.

Oliveira-Filho AT \& Ratter JA. 2002. Vegetation physiognomies and woody flora of the cerrado biome. In: Oliveira-Filho AT \& Marquis RJ (orgs.), The cerrados of Brazil: ecology and natural history of a Neotropical savanna (P.S.): 91-120. Columbia University Press, New York.

Olson ME \& Rosell JA. 2013. Vessel diameter-stem diameter scaling across woody angiosperms and the ecological causes of xylem vessel diameter variation. New Phytol. 197: $1204-1213$.

Paula JE \& Alves JLH. 2007. 897 Madeiras nativas do Brasil. Cinco Continentes, Porto Alegre. 
Peterson CA, Fetcher N, McGraw JB \& Bennington CC. 2012. Clinal variation in stomatal characteristics of an Arctic sedge, Eriophorum vaginatum (Cyperaceae). Amer. J. Bot. 99: $1562-1571$.

Raij B van, Andrade JC, Cantarella H \& Quaggio JA. 2001. Análise química para avaliação da fertilidade do solo. Instituto Agronômico, Campinas.

Reatto A, Correia JR, Spera ST \& Martins ES. 2008. Solos do bioma cerrado. In: Sano SM, Almeida SP \& Ribeiro JF (eds.), Cerrado: ecologia e flora: 107-149. Embrapa Cerrados, Brasília.

Ribeiro JF \& Walter BMT. 2008. As principais fitofisionomias do bioma cerrado. In: Sano SM, Almeida SP \& Ribeiro JF (eds.), Cerrado: ecologia e flora: 151-212. Embrapa Cerrados, Brasília.

Robert EMR, Koedam N, Beeckman H \& Schmitz N. 2009. A safe hydraulic architecture as wood anatomical explanation for the difference in distribution of the mangroves Avicennia and Rhizophora. Funct. Ecol. 23: 649-657.

Salisbury EJ. 1927. On the causes and ecological significance of stomatal frequency, with special reference to the woodland flora. Philos. Trans. R. Soc. London B 216: 1-65.

Sazuka T, Aichi I, Kawai T, Matsuo K, Kitano H \& Matsuoka M. 2005. The rice mutant dwarf bamboo shoot 1: A leaky mutant of the NACK-type kinesin-like gene can initiate organ primordia but not organ development. Plant Cell Physiol. 46: 1934-1943.

Schmitz N, Robert EMR, Verheyden A, Kairo JG, Beeckman H \& Koedam N. 2008. A patchy growth via successive and simultaneous cambia: key to success of the most widespread mangrove species Avicennia marina? Ann. Bot. 101: 49-58.

Sperry JS \& Hacke UG. 2004. Analysis of circular bordered pit function I. Angiosperm vessels with homogeneous pit membranes. Amer. J. Bot. 91: 369-385.

Stone-Palmquist ME \& Mauseth JD. 2002. The structure of enlarged storage roots in cacti. Intern. J. Plant Sci. 163: 89-98.

Strittmatter CGD. 1973. Nueva tecnica de diafanizacion. Bol. Soc. Argent. Bot. 15: 126-129.

Tyree MT, Davis SD \& Cochard H. 1994. Biophysical perspectives of xylem evolution: is there a tradeoff of hydraulic efficiency for vulnerability to dysfunction? IAWA J. 4: 335-360.

Westman WE. 1975. Edaphic climax pattern of the pigmy forest region of California. Ecol. Monographs 45: 109-135.

Xu Z \& Zhou G. 2008. Responses of leaf stomatal density to water status and its relationship with photosynthesis in a grass. J. Experim. Bot. 59: 3317-3325.

Accepted: 20 November 2013 